\title{
Communication Convergence in Village Development Program (Case: Village Fund in Sungai Kali Village, South Kalimantan)
}

\author{
Oki Gusri Anto ${ }^{1, *}$, Dwi Sadono ${ }^{2}$, Dwi Retno Hapsari²
}

${ }^{1}$ Master program in Communication of Agricultural and Rural Development, IPB University, Bogor 16680, Indonesia.
2 Department of SKPM, Faculty of Human Ecology, Bogor Agricultural University, Bogor 16680, Indonesia
${ }^{*}$ E-mail : oki_gusri1357i@apps.ipb.ac.id

Submitted: 19 January 2021 | Accepted: 24 March 2021 | Published online: 8 April 2021

\begin{abstract}
Development and communication are two inseparable factors because a successful development cannot come up without the communication role as a strategy to realize a community welfare. The social inequality and poverty of today is caused by the development that is not in line with the community's real needs or expectations. This triggers disagreements or non-convergent communication among all resource managers in the village. This study uses the theoretical approach of convergence communication model to examine factors that influence the development gaps in terms of individual characteristics, and the supporting environment available and to formulate convergent strategies to solve development gaps. This research is designed with a quantitative approach and qualitative data to identify social behaviors and symptoms in the community. The results showed that communication convergence does not occur in the development programs, which could be affected by low education, income levels and inappropriate policies applied in development to achieve common development goals.
\end{abstract}

Keywords: convergence communication, social inequality, village development, village funding title of the work, journal citation and DOI. 


\section{INTRODUCTION}

A village as the smallest government unit in Indonesia cannot be separated from structural problems resulting in backwardness and poverty. This is of a particular concern for the government. Initially carried out in urban areas only, development is currently focused on rural areas to achieve relatively equal social welfare. The government's efforts to realize a prosperous village community are based on the policies of allocating village funds. According to Law No.6 of 2014 on Villages, village funds are from the State Budget (APBN), transferred through the District/City Budget (APBD) to finance government activities, ranging from the implementation of development, community development, and empowerment of village communities.

Community empowerment according to Noor (2011) is a concept of economic development containing the social values to build a new paradigm in development. Indonesian people actually have their own social power to achieve development goal. Cahyono and Adhiatma (2016) stated this paradigm assumption that growth alone is not enough, thus there needs to be a distribution policy to improve the welfare of rural community, villagers are no longer seen as objects, but as actors of development and development process is directed at improving the quality of human resources. In line with the Ministry of Finance (2017), village funds are allocated by the government to improve the welfare of the rural community and the quality of human life as well as to alleviate poverty through the provision of basic needs, the development of facilities and infrastructure, the development of local economic potential, as well as the sustainable utilization of natural and environmental resources.

Since the introduction of policies on village funds, studies related to management, effectiveness, policy, coordination and others have come up. The development programs will proceed of course through the stages in the management of village funds and principles as stipulated in the Regulation of the Ministry of Home Affairs (2014) on Village Development Guidelines. In general, studies conducted by universities contribute to the phenomena and the implications of policies after the presence of the Village Law. A study by Sari (2015) examines the management of village fund allocation in terms of the procedural aspects of community empowerment: planning, implementation, supervision, accountability and reporting. The study results showed that the development management in terms of community empowerment with village funds was poorly carried out, there were inhibitory factors of synchronization between planning at the village and sub-district levels, and the lack of village fund socialization in the community. Putra et al. (2012) in his research reviewing the management of village fund allocation to empower village communities shows that the Village Fund was used mostly for the operational costs of village government, which is not in accordance with its allocation. On the other hand, Kholmi (2017) in his study reviewed the accountability of village fund allocation management. The results showed that the stages of village fund management, ranging from planning, evaluation to reporting are in accordance with the development policies. However, it found that there was still the lack of understanding among village apparatus in implementing village funds.

The three studies focused on community empowerment and stages in the management of village funds, such as, planning, distribution, implementation, supervision and reporting. Umbara et al. (2018) in his study said in 2015 the government considered the village as the spearhead of development and improvement of community welfare through the Village Fund program. The study has not examined elaboratively why at every stage of development management there is a disagreement between the manager and the community. As can be seen, many problems emerge from the rural development implemented so far - one study of Indonesia Corruption Watch (2019) found 252 cases of village budget corruption throughout 2015-2018 that caused the country to lose 18 Billion at the village government level and the number continues to increase from year to year. Suhendi (2013) in his study said there are social inequalities and poverty as a result of the development process that does not meet the real needs and expectations of the community. The community potential has been neglected in the development process, causing social welfare problems that can arise anywhere, anytime, and against anyone.

The gap between the managers and the community in the development program is caused by the failure of mutual understanding between the managers and the village community, creating 
miscommunications, involving misperception, misconception and distrust from the community (not convergent) which make the development not comply with the common development goals. So far, the development has caused social gaps and symptoms in the community. Social symptoms are always of complex problems. Relevant communication approaches are used to study social cases and symptoms arising in the community, where individual interaction processes in the community are studied or communication processes conducted directly in development programs. In fact, development and communication are two factors that cannot be separated because development cannot succeed without the role of communication as a strategy to realize the social welfare. Ardiyanti (2012) said that the sociology of communication is one that specifically studies social interactions in society, namely looking at relationships or communication that can lead to the process of mutual influence between individuals, individuals with communities and between groups. In order to achieve a successful development, Farihanto (2016) said it takes a continuous communication process which certainly can support to reach the goals of the development.

Mugniesyah (2013) said that convergent communication is a communication model at the individual level involving, perception, understanding and trusting information delivered and received by villagers. The previous three studies have not much discussed the issue, the background of individual characteristics, environmental support, and the process of conveying information that affects interactive communication (convergence) of the community in the development program, so it also has not contributed to the development policy of the Village Fund. Next Mulyandari et al. (2010) in his research said a continuous integration of interests between related parties encourages each party to interact and communicate proactively and anticipatory through knowledge sharing that supports and strengthens each other to meet common needs.

Given the background above, it is of our interest to conduct a study on village development viewed from a convergent communication model, which is used to analyze a communication at the individual level involving perception, understanding and trusting information in the development program carried out in Sungai Kali Village. This study was conducted to see the influence of individual characteristics and environmental support on convergent communication in the rural development program and also offers an appropriate and effective strategy in rural development program to achieve common development goals.

\section{RESEARCH METHODS}

This study was designed with quantitative and qualitative data to obtain facts of existing phenomena and attempts to explain and describe the facts and phenomena observed. According to Bungin (2017) quantitative approach emphasizes on social behaviors that have real, measurable, observable symptoms as variables in society. The qualitative data was obtained from observations and in-depth interviews with informants.

Data was collected with a random sample withdrawal (purposive) of 147 people from February to March 2020. This study respondents were people in Sungai Kali Village, Barito Kuala Regency, South Kalimantan. The research sample took into account the level of communication and community involvement or interaction in the village development activities. Statistical analysis of inference was used in this study to answer research objectives by using Partial Least Square (PSL) with the help of Smart PLS 3.0 application. PLS analysis was also used to formulate strategies in development.

\section{RESULTS AND DISCUSSION}

\section{Characteristics of Individuals in Village Development}

Individual characteristics are one of the variables observed in this study, which include age, education level, and income level of the sample. With respect to age, Table 1 shows that on average the people of Sungai Kali Village participating in the village development are at the middle age (36-45 years). This means that middle (productive) age is more active and often involved in the development programs of Sungai Kali Village. Further, generally their educational background is relatively low, 
consisting of four educational levels (not completed elementary included): elementary, junior high, high school and tertiary, classified into two categories, namely: low educational level (not-completed elementary, elementary and junior high school) and higher education level (senior high school and bachelor / college). The distribution table below shows people with a low level of education account for $78.9 \%$, people of Sungai Kali Village with higher education reach $21.09 \%$. The low education is caused by weak and insufficient economic factors to continue education to higher levels such as High School and Higher Education.

Table 1 Number and percentage of individual characteristics in village development

\begin{tabular}{|c|c|c|c|}
\hline \multirow{2}{*}{ Individual Characteristics } & \multirow{2}{*}{ Categories } & \multicolumn{2}{|c|}{ Sum $(n=147)$} \\
\hline & & Person & $\%$ \\
\hline \multirow{3}{*}{ Age } & - $\quad$ Early adult ( $26-35$ years old $)$ & 58 & 39.46 \\
\hline & - $\quad$ Middle age (36- 45 years old) & 60 & 40.82 \\
\hline & - $\quad$ Old age $(46-55$ years old $)$ & 29 & 19.73 \\
\hline \multirow{5}{*}{ Last education } & - uncompleted elementary school & 11 & 7.48 \\
\hline & - $\quad$ Elementary school & 50 & 34.01 \\
\hline & - Junior high school & 55 & 37.41 \\
\hline & - Senior high school & 23 & 15.65 \\
\hline & - $\quad$ Tertiary & 8 & 5.44 \\
\hline \multirow{3}{*}{ Income level } & - Low & 124 & 84.35 \\
\hline & - $\quad$ Are & 19 & 12.93 \\
\hline & - $\quad$ High & 4 & 2.72 \\
\hline
\end{tabular}

In terms of income, the people of Sungai Kali Village are closely related to agriculture and plantations. Their income level is of a low category as result of some factors, one of which is that the village is located far enough from the city center, thus agricultural products and plantations are sold at low prices directly to collectors. In addition, the village lies on the stretch of The Barito River and the swamp area with frequent crop failures due to the soil acidity and the tides of rivers and seas that make their land flooded. The low-income level of the community tends to affect them in making decisions to act and their interactive communication in the development programs carried out in Sungai Kali Village. In line with that, Soekartawi (2005) in his book entitled the basic principle of agricultural communication says that low-income farmers tend to be slow at obtaining messages, whereas farmers with higher-incomes tend to be faster at receiving messages.

\section{Environmental Support in Village Development}

Based on Law No. 6 of 2014 on Villages, the village government has the right of origin and traditional rights in regulating and taking care of the interests of the local community and plays a role in realizing the social welfare of the village. Mustanir and Darmiah (2016) in their studies said that the leader (village head), in implementing a policy on the management of village funds in the development program, greatly affects morale, job satisfaction, security and the effectiveness of a development felt by the village community. To achieve the objectives of the development program, environmental supports (such as the suitable policy implementation, available communication facilities and infrastructure, supportive local institutions, the use of language and culture) require a synchronous managerial pattern of development in order that the results of development and other government programs can be felt and enjoyed by the community.

The indicators of environmental support observed in this study are government policies (implemented policies that conform to the development program management, available transportation facilities, available communication facilities and agency support), and culture (language, values and norms) in 
the village development. The study results related to government policies (Table 2) show a lack of appropriate policy implementation by the Kali village government in the development program, in addition to unavailable transportation facilities to meet the needs of development. Furthermore, communication facility (media) to support the dissemination of information related to the development is also inadequate or limited, making many people unaware of the details and stages of the development programs.

With respect to institutional support, the village government such as BPD does not appear to be active and supportive of the development programs, and this, in Kali Village in the development program, is caused by the power of the village head in determining his or her trusted personnel appointed to carry out tasks and activities in the development management. In line with that, Hermansyah (2018) said that the role of the village head in the development is the determinant of whether or not the results of the development will be achieved, whether it is in accordance with the common development plan or is still far from initial expectations.

Table 2 Number and percentage of environmental support in village development

\begin{tabular}{|c|c|c|c|}
\hline \multirow{2}{*}{ Environmental Support } & \multirow{2}{*}{ Categories } & \multicolumn{2}{|c|}{$\operatorname{Sum}(\mathrm{n}=147)$} \\
\hline & & Person & $\%$ \\
\hline \multirow{3}{*}{$\begin{array}{l}\text { Conformity of implemented } \\
\text { policy with development } \\
\text { program management }\end{array}$} & - $\quad$ Appropriate & 29 & 19.73 \\
\hline & - Less appropriate & 118 & 80.27 \\
\hline & - Not appropriate & 0 & 0 \\
\hline \multirow{3}{*}{$\begin{array}{l}\text { Availability of transportation } \\
\text { facility }\end{array}$} & - $\quad$ Available & 0 & 0 \\
\hline & - $\quad$ Less available & 50 & 34.01 \\
\hline & - Not available & 97 & 65.99 \\
\hline \multirow{3}{*}{$\begin{array}{l}\text { Availability of communication } \\
\text { facility }\end{array}$} & - $\quad$ Available & 0 & 0 \\
\hline & - Less available & 142 & 96.60 \\
\hline & - Not available & 5 & 3.40 \\
\hline \multirow[t]{3}{*}{ Agency support } & - $\quad$ Support & 0 & 0 \\
\hline & - $\quad$ Less supportive & 91 & 61.90 \\
\hline & - $\quad$ Not supported & 56 & 38.10 \\
\hline \multirow[t]{3}{*}{ Language usage } & - $\quad$ Understandable & 91 & 61.90 \\
\hline & - $\quad$ Lack of understanding & 56 & 38.10 \\
\hline & - $\quad$ Not understood & 0 & 0 \\
\hline \multirow[t]{3}{*}{ Value } & - $\quad$ Appropriate & 69 & 46.94 \\
\hline & - $\quad$ Less appropriate & 78 & 53.06 \\
\hline & - $\quad$ Not appropriate & 0 & 0 \\
\hline \multirow[t]{3}{*}{ Standard } & - $\quad$ Appropriate & 71 & 48.30 \\
\hline & - Less appropriate & 76 & 51.70 \\
\hline & - Not appropriate & 0 & 0 \\
\hline
\end{tabular}

Indicators of cultural environmental support (language, values and norms) in Table 2 show that people of Sungai Kali Village can understand the information delivered about the development program, but not all messages or information can be fully understood. In relation to this, Mulyandari et al. (2016) said the language use viewed to be good could be rejected by the targeted communities in certain areas because it is disliked or inappropriate in the circumstances. Next, the indicators of values and norms 
adopted in the development program of the village are seen as not conforming with what the people of Sungai Kali Village have been experiencing so far. This is because there are many irregularities in the management of development programs - different from the values and norms practiced and believed by the village community. This study found that the early stages of financial disbursement in the development planning did not operate as expected. The funding was slowed down from the treasurer due to the intervention by the village head borrowing for personal funds, thus disrupting the use of initially planned development funds. This fact had an impact on the implementation of projects and activities of the village development programs.

\section{Communication Convergence in Village Development}

The communication convergence referred to in this study is to see how the realities occurring during the communication process take place between the village government and the community in the development program. The communication process is seen at the individual level of society where information and mutual understanding is the end result of the communication process based on collective action, agreement and mutual understanding among the communicating participants. Convergent communication in this study has several indicators: perceiving, understanding and trusting. The study results (Table 3) show that in general the people of Sungai Kali Village do not know the existence of village funds and do not understand the allocated village funds to finance the administration, and implementation of community development and community empowerment because there is a lack of information provided by the village officials to the community. This has made the community distrust the village government in the management of development programs financed by the village funds.

Table 3 Number and percentage of communication convergence in village development

\begin{tabular}{|c|c|c|c|}
\hline \multirow{2}{*}{ Communication Convergence } & \multirow{2}{*}{ Categories } & \multicolumn{2}{|c|}{ Sum $(n=147)$} \\
\hline & & Person & $\%$ \\
\hline \multirow[t]{3}{*}{ Perceiving } & Know & 0 & 0 \\
\hline & - $\quad$ Know little & 81 & 55.10 \\
\hline & - $\quad$ Do not know & 66 & 44.90 \\
\hline \multirow[t]{4}{*}{ Understanding } & - $\quad$ Understand & 0 & 0 \\
\hline & - $\quad$ Understand & 6 & 4.08 \\
\hline & little & 141 & 95.92 \\
\hline & $\begin{array}{l}\text { - Do not } \\
\text { understand }\end{array}$ & & \\
\hline \multirow[t]{3}{*}{ Believing } & - $\quad$ Believe & 17 & 11.56 \\
\hline & - $\quad$ Believe little & 127 & 86.39 \\
\hline & $\begin{array}{l}\text { - Do not } \\
\text { believe }\end{array}$ & 3 & 2.04 \\
\hline
\end{tabular}

For the residents, the presence of village funds in reality brings out new issues and problems in the relationship between residents and the village government (village apparatus) because it does not conform to the expectations of the village community, but it enriches the village head and his trusted staff only. Many cases of mismanaged village funds are considered as distorted by the community because it is not openly socialized to the community, making the development not meet the reality and targeted users. Given such a case, communication convergence (mutual understanding) does not occur in the development program, as a result many people have misperceptions, do not understand and do not believe in the development programs carried out. Relate to this, Nurhadi (2017) in his study stated that although communication has been developed into a science, but in reality it is still often encountered that misunderstanding and miscommunication come up among the communicators themselves, which in turn leading to disagreements on the message they are delivering. 


\section{Influence of Individual Characteristics, Environmental Support on Communication Convergence in Development}

Individual characteristics are inherent part of the personal traits of a person. According to Humaidi et al. (2020) in their research said that individual characteristics rely on the behavior of individuals in work and other situations. The study results showed that individual characteristic variables have a significant effect of $5 \%$ on communication convergence with an estimated value of original sample in positive value of 0.165 or $16.5 \%$, an indicator of education level of 0.980 , and income level of 0.535 . Generally, the educational level of the community in this study is relatively low - some do not complete elementary school, some graduate from elementary school and some graduate from junior high schools. The field facts in the study show that the level of education greatly influences interactive communication (convergence) in terms of perception, understanding and trust of the people of Sungai Kali Village in receiving and analyzing the information obtained. Further, such a low educational background in Sungai Kali Village has caused miscommunications or gaps in receiving and understanding the information related to the development programs, thus the non-convergent communication is characterized by differences in understanding the meaning and purpose of the development programs. In line with this, Putra (2018) in his study said that education has an important role in one's life because the higher the education, the wider the knowledge and the higher the analytical power of the person to solve the gaps encountered in communication to create mutual understanding or convergent understanding between each other.

The low education discussed in this study was caused by weak and insufficient economic factors to continue education to higher levels such as Senior High School (SMA) and Higher Education. The low-income level of the people of Sungai Kali Village has affected the convergent communication (interactive) in village development programs. The field facts show that people with low incomes tend not to attend or have limited time to participate in the development programs because they prefer working as farmers to increase their income. In this respect, Nurbaiti et al. (2017) in their studies stated that the level of income will provide a great opportunity for people to participate in activities in which they will involve themselves because this can improve their financial ability, by directing all abilities if this is in line with their priorities and needs.

Table 4 Direct effect of individual characteristics, environmental support on communication convergence in village development

\begin{tabular}{lcccc}
\hline Relationships Between Latent Variables & $\begin{array}{l}\text { Original } \\
\text { Sample }\end{array}$ & $\begin{array}{l}\text { Standard } \\
\text { Deviation }\end{array}$ & $\begin{array}{l}\text { T } \\
\text { Statistics }\end{array}$ & $\begin{array}{l}\text { P } \\
\text { Values }\end{array}$ \\
\hline $\begin{array}{l}\text { Individual Characteristics (X1) } \rightarrow \\
\text { Communication Convergence (Y) }\end{array}$ & 0.165 & 0.075 & 2.198 & $0.028^{*}$ \\
\hline $\begin{array}{l}\text { Environmental Support (X2) } \rightarrow \\
\text { Communication Convergence (Y) }\end{array}$ & 0,611 & 0,072 & 8,474 & $0,000^{*}$ \\
\hline Notes: $*$ Significant at a rate of 5\% & & & &
\end{tabular}

Notes: * Significant at a rate of $5 \%$.

The convergence of communication in this environmental support is to see the influence of environmental support in Sungai Kali Village such as government policies (conformity of implemented policies to the development program management, available transportation facilities, available communication facilities and institutional support), and culture (use of language, values and norms) on the process of communication convergence with such indicators as perceiving, understanding and trust during the village development programs implemented. The study results in Table 5 show that environmental support variables affected the emergence of interactive (convergent) communication in the development program, with the value of 0.61 or $61 \%$. The value of environmental support (government policy) for the conformity indicator of implemented policy is 0.776 , the indicator of the available transportation facilities is 0.847 , the indicator of the available communication facilities is 0.747 and the indicator of institutional support is 0.772 . Further, as for the environmental (cultural) support variables, the language usage indicator is 0.678 , a value indicator of 0.628 and a norm indicator of 0.538 . The lack of environmental support (especially the minimal 
availability of information facilities and information provided by village officials to the community) in the development program in Sungai Kali Village greatly influences the convergent communication, besides the policies applied by village officials in the development programs that also influence communication convergence to achieve mutual understanding. In this respect, Purwaningsih (2008) and Anwas (2013) in their research said that environmental supports affect the competence of extension workers and the farmers' decision to adopt a partnership pattern involving conformity, availability of transportation and telecommunications facilities, availability of learning facilities, availability of loans and source of information, all of which should create an atmosphere that encourages the improvement of extension competence.

\section{Convergent Communication Implementation Strategy in Managing Village Fund for Development}

The convergent communication strategies in this study for development is the formulation resulting from deductive studies and empirical testing. Therefore, the strategy in this study is a comprehensive and integrated entity to achieve goals through various alternative methods or strategies adopted, implemented and evaluated in order to be more effective and efficient. In this respect, according to Siagian (2016), a strategy is a series of fundamental decisions and actions made by the top management and applied by all ranks in an organization in order to achieve the organization's goal.

The absence of interactive (convergent) communication in Sungai Kali Village is due to several factors: low education, low income level of the people of Sungai Kali Village (which can affect public knowledge of the functions and policies of village funds), low environmental support (lack of available information facilities and media), and low participation of local institutions in the development program (which also affects the emergence of convergent communication and mutual understanding between the village government and the village community).

The strategic steps, required to improve convergent communication, and thus creating mutual understanding in the development program, based on the results of the analysis of individual characteristics and environmental support in Sungai Kali Village in the development program, are as follow: (1) increasing the intensity of communication between the community and the village government concerning the development program; (2) improving awareness of village apparatus (managers) to be more active in providing information about development programs to the community; (3) increasing the availability of information facilities for the people of Sungai Kali Village; (4) increasing the availability of village transportation facilities for community use in emergencies; (5) improving the quality of human resources (village apparatus) by increasing the intensity of training/guidance in the management of development programs using village funds; and (6) increasing the activeness of supporting institutions, such as BPD to play an active role in the development programs.

\section{CONCLUSION}

The development programs carried out in Sungai Kali Village is still of a top-down approach or dominated by the village elite to carry out the development. Convergent communication (mutual understanding) does not occur in the development. Individual characteristics have a significant effect on the convergence of communication during the implementation of development. It is the variable of individual characteristics that have a significant influence. Environmental support also greatly affects the emergence of interactive (convergent) communication in the development programs. Environmental support factors that are not appropriate and less supportive also influence development. To improve convergent communication (mutual understanding) in development, an effective strategy should be formulated in creating development that could achieve the common goals and could be felt by the villagers.

\section{REFERENCES}

Anwas, O. . (2013). Pengaruh pendidikan formal, pelatihan dan intensitas pertemuan terhadap kompetensi penyuluh pertanian. Pendidikan Dan Kebudayaan, 19 No 1.

Ardiyanti, H. (2012). Konflik Sampang: Sebuah Pendekatan Sosiologi-Komunikasi. Sosiologi 
Komunikasi, 3 No.2, 225-241.

Bungin, B. M. (2017). Metodologi Penelitian Kuantitatif: Edisi Kedua (A. Supriyatna (ed.); 2nd ed.). Kencana.

Cahyono, B., \& Adhiatma, A. (2016). Peran modal sosial dalam peningkatan kesejahteraan masyarakat petani tembakau di Kabupaten Wonosobo. Conference In Business, Accounting, And Management (CBAM).

Farihanto, M. N. (2016). Dinamika komunikasi dalam pembangunan Desa Wisata Brayut Kabupaten Sleman. Jurnal Penelitian Pers Dan Komunikasi Pembangunan. https://doi.org/10.46426/jp2kp.v19i3.37

Hermansyah Asep, P. R. (2018). Pengaruh Kepemimpinan Kepala Desa Terhadap Pelaksanaan Pembangunan Fisik di Desa Sindanglaya Kecamatan Karangpawitan Kabupaten Garut. Pembangunan Dan Kebijakan Publik, 09 No 01.

Humaidi, L., Hubeis, A. V. S., Puspitawati, H., \& M Anwas, O. E. (2020). Karakteristik Penyuluh Dalam Pemanfaatan Media Sosial Sebagai Media Informasi Pertanian. Agrisocionomics: Jurnal Sosial Ekonomi Pertanian. https://doi.org/10.14710/agrisocionomics.v4i1.6113

Kementerian Keuangan. (2017). Buku saku dana desa. Kementerian Keuangan Republik Indonesia.

Kholmi, M. (2017). Akuntabilitas Pengelolaan Alokasi Dana Desa (Studi di Desa Kedungbetik Kecamatan Kesamben Kabupaten Jombang). Journal of Innovation in Business and Economics. https://doi.org/10.22219/jibe.vol7.no2.143-152

Mulyandari, Retno Sri Hartiti., Sumardjo., Pandjaitan, Nurmala K., Lubis, D. P. (2010). Pola komunikasi dalam pengembangan modal manusia dan sosial pertanian. Forum Penelitian Agro Ekonomi, 28 No.2, 135-158.

Mulyandari, R. S. H., Sumardjo, S., Pandjaitan, N. K., \& Lubis, D. P. (2016). Pola komunikasi dalam pengembangan modal manusia dan sosial pertanian. Forum Penelitian Agro Ekonomi. https://doi.org/10.21082/fae.v28n2.2010.135-158

Mustanir, A., \& Darmiah, D. (2016). Implementasi kebijakan dana desa dan partisipasi masyarakat dalam pembangunan di Desa Teteaji Kecamatan Telu Limpoe Kabupaten Sidendreng Rappang. Jurnal Politik Profetik.

Noor, M. (2011). Pemberdayaan Masyarakat. Jurnal Ilmiah CIVIS, 1 No.2, 87-99.

Nurbaiti, Siti Robiah., Bambang, A. N. (2017). Faktor - faktor yang mempengaruhi partisipasi masyarakat dalam Pelaksanaan program Corporate Social Responsibility (CSR). Proceeding Biology Education Conference, 14 No.1, 224-228.

Nurhadi, Zikri Fachrul., Kurniawan, A. wildan. (2017). Kajian tentang efektivitas pesan dalam komunikasi. Jurnal Komunikasi Hasil Pemikiran Dan Penelitian, 3 No.1, 91-95.

Peraturan Kementerian Dalam Negeri (Permendagri). (2014). Peraturan Kementerian Dalam Negeri (Permendagri) tentang Pedoman Pembangunan Desa. Kementerian Dalam Negeri.

Prananda Putra, A. (2018). Pengaruh Tingkat Pendidikan dan Persepsi Terhadap Partisipasi Masyarakat Dalam Pengelolaan Daya Tarik Wisata Air Terjun Selendang Arum, Songgon Banyuwangi. Jurnal Master Pariwisata (JUMPA). https://doi.org/10.24843/jumpa.2018.v05.i01.p09

Purwaningsih, E. (2008). Partisipasi masyarakat dalam pembangunan desa. Jurnal Jantra, 3 No.6, 443-452.

Putra, C. K., Pratiwi, R. N., \& Suwondo. (2012). Pengelolaan alokasi dana desa dalam pemberdayaan masyarakat desa (studi pada Desa Wonorejo Kecamatan Singosari Kabupaten Malang). Jurnal Administrasi Publik (JAP).

Sari, R. (2015). Pengelolaan Alokasi Dana Desa Dalam Perspektif Pemberdayaan Masyarakat (Studi Pada Kantor Pemerintahan Desa Ngasem, Kecamatan Ngasem, Kabupaten Kediri). Jurnal Administrasi Publik Mahasiswa Universitas Brawijaya. 
Siagian, S. P. (2016). Buku Manajemen Sumber Daya Manusia. Bumi Aksara.

Soekartawi. (2005). Prinsip Dasar Komunikasi Pertanian. RajaGrafindo Persada, 2005.

Suhendi, A. (2013). Peranan tokoh masyarakat lokal dalam pembangunan kesejahteraan sosial. Informasi.

Umbara, D., Kamaluddin, M., \& Tawai, A. (2018). Implementasi kebijakan dana desa dalam upaya mewujudkan efektivitas program pembangunan desa di Kecamatan Lalembuu Kabupaten Konawe Selatan. Jurnal REZ Publica.

Wacht, I. C. (2019). Dana Desa Merugikan Negara Mencapai 18 Miliar. Indonesia Corruption Watch (ICW). 